\title{
Correction to: Headwater Mires Constitute a Major Source of Nitrogen (N) to Surface Waters in the Boreal Landscape
}

\author{
Ryan A. Sponseller, ${ }^{1 *}$ M. Blackburn, ${ }^{2}$ M. B. Nilsson, ${ }^{2}$ and H. Laudon ${ }^{2}$ \\ ${ }^{1}$ Department of Ecology and Environmental Science, Umea University, Umeå, Sweden; ${ }^{2}$ Department of Forest Ecology and Man- \\ agement, Swedish University of Agricultural Sciences, Umeå, Sweden
}

\section{Correction to: Ecosystems}

DOI: 10.1007/s10021-017-0133-0

The authors discovered an error in the discharge calculation for the mire outlet stream (MC4) that led to an underestimation of nitrogen $(\mathrm{N})$ export from this catchment. This error has no influence on the overall message or conclusions of the paper but does suggest even greater relative $\mathrm{N}$ losses from the mire-dominated catchment. Accordingly, our estimates of dissolved organic N (DON) export from MC4 for 20092011 should have been reported as 1.4, 1.2, and $1.5 \mathrm{~kg} \mathrm{~N} \mathrm{ha}^{-1} \mathrm{y}^{-1} \quad\left(\right.$ average $\left.=1.4 \mathrm{~kg} \mathrm{~N} \mathrm{ha}^{-1} \mathrm{y}^{-1}\right)$. Estimates of dissolved inorganic $\mathrm{N}$ (DIN) export for the same years were $0.18,0.18$, and $0.19 \mathrm{~kg} \mathrm{~N} \mathrm{ha}^{-1} \mathrm{y}^{-1}$ (average $=0.18 \mathrm{~kg} \mathrm{~N} \mathrm{ha}^{-1} \mathrm{y}^{-1}$ ). If we assume that $\mathrm{N}$ export from this site was derived solely from the MC4 mire, then average losses of DON and DIN would be 3.1 and $0.41 \mathrm{~kg} \mathrm{~N} \mathrm{ha}^{-1} \mathrm{y}^{-1}$, respectively, for 20092011. If we assume that forests contributed $\mathrm{N}$ in proportion to their cover in the catchment, then the average export of DON and DIN from the MC4 mire would be 2.7 and $0.36 \mathrm{~kg} \mathrm{~N} \mathrm{ha}^{-1} \mathrm{y}^{-1}$, respectively, for 2009-2011. Finally, the corrected discharge data resulting in subtle changes to the daily export estimates for MC4 illustrated in Figure 3, which is updated here.

published online 5 February 2018

The original article can be found online at https://doi.org/10.1007/ s10021-017-0133-0.

*Corresponding author; e-mail: ryan.sponseller@umu.se 

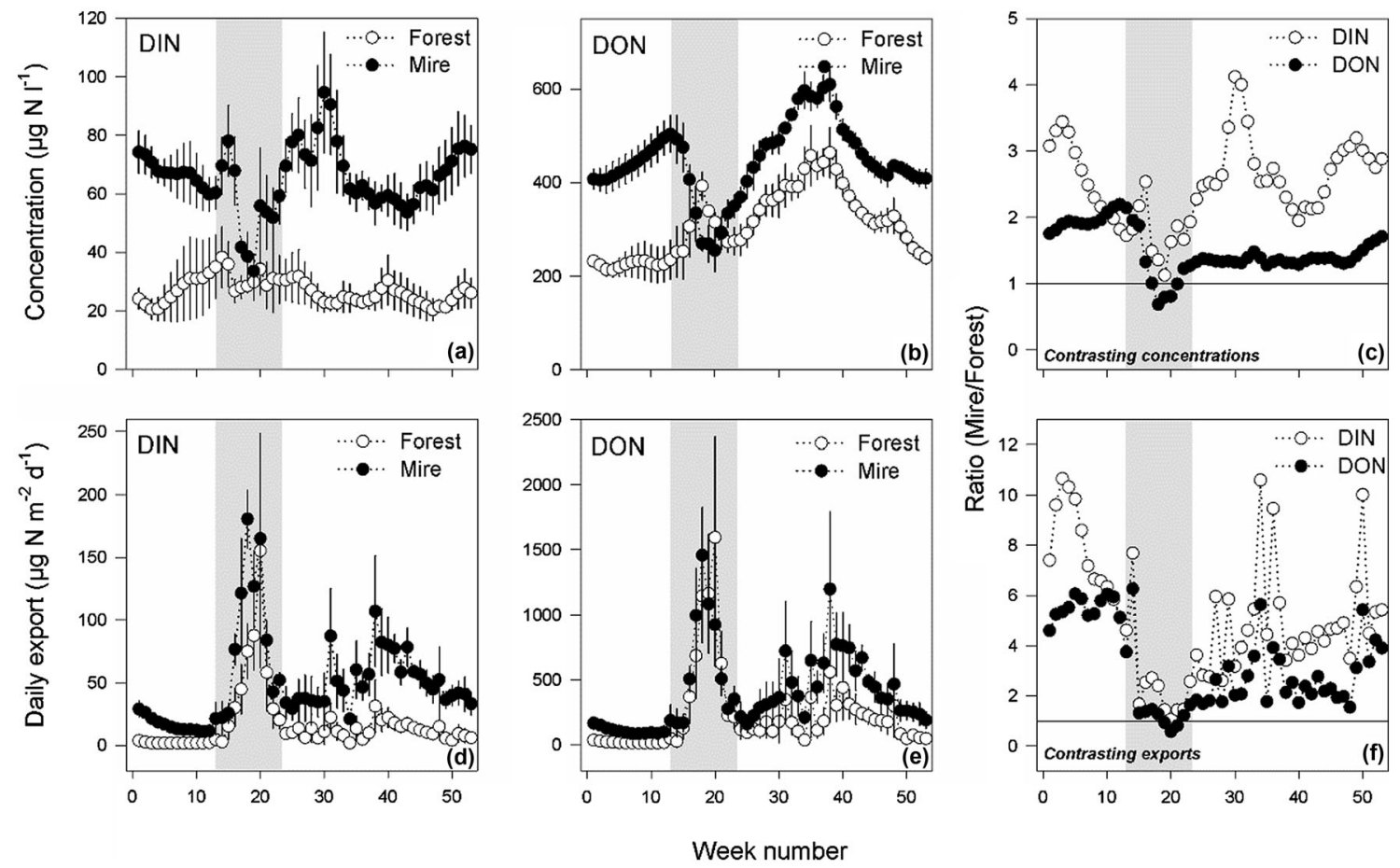

Figure 3. Representation of seasonal trends in the concentration and export of DIN and DON for mire (MC4) and forest (FC2) catchments. Top panels $\mathbf{A}$ and $\mathbf{B}$ show the weekly average concentration ( \pm SE); bottom panels $\mathbf{D}$ and $\mathbf{E}$ show daily export averaged by week $( \pm \mathrm{SE})$. Averages are derived from the interpolated daily time series record generated between 2008 and 2012; standard errors are based on differences among years ( $n=4$ or 5). Right panels $\mathbf{C}$ and $\mathbf{F}$ illustrate the difference between MC4 and FC2 as described by the ratio of concentration (panel $\mathbf{C}$ ) and export (panel F) on a weekly basis for the same period. Gray shading indicates the spring snowmelt period. 